\title{
Eric Voegelin's History of political ideas. The bones of contention of the political animal
}

\author{
M. Castro-Henriques
}

Universidade Católica Portuguesa (UCP)

Palma de Cima, 1649-023 Lisbon, Portugal

\begin{abstract}
The History of Political Ideas by the German-American philosopher Eric Voegelin (1901-1985) is a monumental work of around 2,600 pages. It remained unpublished during his lifetime, and it came to light through the American edition (1997-1999) and the now completed Portuguese edition (2012-2018). Being the author of the first world edition of an abridged version of the History of Political Ideas; the translator of the first three volumes of the 2012-2018 Portuguese edition; and the author of The civil philosophy of Eric Voegelin (my $1990 \mathrm{Ph}$. D diss.) I consider that the History of Political Ideas challenges the present climate of opinion: it subverts the dominant corrosive forces of moral relativism, intolerant neo-positivism, end-of-history obsessions, postmodernist deconstructions, agnosticism, nihilism, new age religions, and the all-pervasive ideology of money. Eric Voegelin achieves all this leading his readers from Antiquity to Modern Age. His monumental work begins with the "spiritual disintegration" of the Greek world, after the peak of Plato and Aristotle, a disintegration that ushered a long process of transition in the self-understanding of man in the Mediterranean world. The series goes through Middle Ages, Renaissance and Reformation as Voegelin analyzes the collapse of imperial Christianity, which led to the rise of autonomous reason and sectarian revolts that reached full development in later centuries. A new form of modern human consciousness replaced the Christian understanding of a divinely created closed cosmos. The collection ends - in a suspensive way - with "The Crisis and the Apocalypse of Man" focused on thinkers such as Comte, Bakunine and Marx; although they experienced true epiphanies, they become self-obsessed to the detriment of the world to which they refer. Such "Apocalypse of Man" must now be challenged, albeit with methodologies and hermeneutic principles other than those that Voegelin himself abandoned some decades ago.

Keywords: philosophy, political science, history of ideas, political history, spiritual realism, civil theology, methodology, enlightenment, reformation, positivism
\end{abstract}

\section{Article history:}

The article was submitted on 12.08.2019

The article was accepted on 24.09.2019

C Castro-Henriques M., 2019

This work is licensed under a Creative Commons Attribution 4.0 International License https://creativecommons.org/licenses/by/4.0/ 
For citation: Castro-Henriques M. Eric Voegelin's History of political ideas. The bones of contention of the political animal. RUDN Journal of Philosophy. 2020; 24 (1): 99-112. DOI: $10.22363 / 2313-2302-2020-24-1-99-112$

\section{The man and the work}

Eric Hermann Wilhelm Voegelin was born with the 20th century on January 3, 1901 in Koln, Germany. He lived in Vienna, Austria, until 1938. Persecuted by the Nazis, he immigrated to the United States, and settled in Louisiana. In 1958 he went back to Munich, to create the Institute of Political Sciences. In 1969 he returned to the USA, settling in Stanford, California, where he died on January 19, 1985, as an American citizen. His Autobiographical Reflections, published posthumously in 1989, show the experience and friendships he gained in Europe and America in a life of labour. His work, at the crossroads of political philosophy, social sciences and theology, is monumental. From the early articles of the 1920s to the posthumous publications in the Collected Works, he searched the foundations of political science, understood in the broad sense of philosohia peri ta anthropina.

In his articles and monographs of Vienna's time, he insists that political science lingers as an image of reality until animated by philosophy. In writing the History of Political Ideas, 1939-1945, he realized that understanding human historical experience requires a previous understanding of the experience of "order", t.i., the participation of man in God's life. The New Science of Politics, 1952, is a first illustration of this new level of research. In Order and History (vols. I, II and III) he presents a new view of man and society; they are open or closed according to how they respond to the tension between order in personal consciousness and concrete social order. Anamnesis, 1966, deepens a philosophy of consciousness, based on the classical experience of rationality and a critique of idealism. Voegelin attained a final level of research in The Ecumenical Age (1974) and In Search of Order (1987) (vols. IV and V). He emphasized how the various configurations of the tension between consciousness and the world penetrate symbolisms. In this intercultural mosaic, Christian revelation emerges as a last resource. Faith in reason becomes tangible in the light of the search for the unknown god, which precedes revelation in history so much as the order of society does not live up to our expectations.

When Eric Voegelin came to United States, he settled in 1939 at Louisiana State University, where he remained for sixteen years. He taught introductory courses in Comparative Political Science, Public Law and Public Administration and, occasionally, Diplomatic History and Comparative Politics. He resumed his project to write a three-part Staatslehre about the doctrines of law, power, and political ideas. The first two parts were ready, but he considered inadequate his knowledge of political ideas ${ }^{1}$. Then, he was invited by Fritz Morstein-Marx, his Harvard acquaintance and editor at McGraw-Hill House, to write a 250-page book

\footnotetext{
${ }^{1}$ Autobiographical Memoir [1. P. 38]: “...I knew nothing whatsoever about political ideas and had to give up the project of a Staatslehre".
} 
about political ideas. The plan grew to such an extent that Voegelin proposed a much larger volume, to Mac Millan publishers. Without waiting for an answer which did not arrive - he started the 2,611 typewritten pages that compose the History of Political Ideas, never published during his life and now brought to light by the Louisiana State University edition (1997-1999) and the Portuguese edition (2012 - 2019), an initiative of Edson Júnior, CEO of the São Paulo's publishing house É Realizações.

It may not be very useful, neither feasible, to summarize 2,600 pages in this paper but I prompt some guidelines about the eight volumes ${ }^{2}$.

Hellenism, Rome, and Early Christianity (vol. 1) demonstrates that the "spiritual disintegration" of the Greek world has ushered a long process of transition in the self-understanding of man in the Ancient Mediterranean world. The volume reflects universal concerns about the order of human existence in society and history.

Medieval political thought (vol. 2) begins with a survey of the structure of that historical period and proceeds with an analysis of the Germanic migrations/invasions, the fall of Rome, and the rise of monastic and imperial Christendom.

In Late Middle Ages (vol. 3) Eric Voegelin explores one of the most important periods in the history of political thought, comenting authors such as William of Ockham, Dante, Egidio Romano, Marsilio of Padua, Piers Plowman, and Cola di Rienzo; he traces back the historical forces of modern world to symbols discovered by the medieval civilization.

Renaissance and Reformation (vol. 4) is a critique of modern political ideologies. Voegelin analyzes the collapse of the unity of imperial Christianity, which led to the rise of autonomous reason and sectarian revolts that reached a full development in later centuries.

Religion and the Rise of Modernity (vol. 5) examines the emergence of modernity in the $16^{\text {th }}$ century debates, philosophical and political. This is a controversial and revolutionary era, encompassing a range of events triggered by Luther's NinetyFive Theses. Voegelin's suggests lines of change that converge to a point: the medieval Christian understanding of a divinely created closed cosmos was replaced by a new form of modern human consciousness, which presupposed man as the origin of the meaning of the universe.

Revolution and the New Science (vol. 6) confronts "methodological" issues that had been circumvented or dealt with indirectly when dealing with the political events and ideas of earlier historical times. Based on the systematic analysis of the "materials," the volume focus into what we now call the question of historicity.

The New Order and the Last Orientation (vol. 7) is the penultimate volume and analyzes key writers of modern political thought; "the new order" and "the last orientation" authors, preceding "the contemporary crisis'. The English Puritan Revolution; Machiavelli, Bodin and Hobbes; the mysticisms of Espinosa and Nietzsche; Schelling's rediscovery of the primacy of existence over political organization;

\footnotetext{
${ }^{2}$ See Bibliography.
} 
Pascal's emphasis on man's finitude rather than progress. These are some of the themes of this provocative and enlightening volume.

Crisis and the Apocalypse of Man (vol. 8) the last volume of the History of Political Ideas, is not so much a conclusion, as a question mark about the plot through which Eric Voegelin led us from antiquity to modern age. The volume focus on thinkers who became obsessed with their own epiphanies, to the detriment of the world to which they refer. The superficiality of the Enlightenment; its political consequences in the French Revolution: Comte's positivism about the divine value of civilizational achievements; Karl Marx's ambition to radically understand matter as the stuff of existence. Those solutions transformed the divine apocalypse into a human apocalypse. Realizing the magnitude of such misconceptions, and their existential inconsistency, Voegelin abdicates to give a final answer within the methodological scope of his unfinished and monumental series of studies.

We must compare Eric Voegelin's endeavour with most histories of political theory that expose ideas or concepts as circumstantial and justify them by a supposed "march of history". Moreover, current histories of political ideas frequently disclose an anti-religious and anti-humanist profile, forgetting that concepts are born in human consciousness. Modern age is unilaterally seen as a culminating period of intellectual and cultural liberation. Whereas is obvious that our age showed monumental progress in fostering human rights - the right to have rights, as Hanna Arendt put it - we also live in an era of totalitarianism, fundamentalism and genocide. Such bleak aspects of modernity are forgotten when spiritual realism is lacking; and anamnesis discloses the preconditions for a History of Political Ideas

1. Political philosophy addresses the question of the order of humanity through the unique development of man.

2. The development of the consciousness of order began in the primitive democracy of the Hebrew people and moved to Greek political theory with questions such as "What is the best way of life"? The answer "the life of the righteous" is the only worth living. Christianity received this heritage and projected it for a universal humanity guided by theological truths.

3. Reason and belief are both of a rational order, as stated by the adage Credere ut inteligere. As Michael Polanyi has argued, even scientists rely on principles of knowledge developed outside their specialty and act on the unspoken belief that one series of experiments will yield better results than another. As Plato stated, (Republic) man is responsible for his actions, and God is transcendent, not intra-cosmic, nor guilty of human evils: the gods are the origin of good, not evil, and do not change form.

4. Modern political philosophy breaks with the order of history in Hellas, Israel, and Christianity. This rupture: a) considers the revealed Christian truth irrational; b) makes a radical dichotomy between subject and object; c) gives priority to self over community; d) abstains from value judgments; e) proposes a civil religion to supplant Christian theology; f) affirms unilaterally the rights of man as the 
right to minorities' difference against natural law. In its most pernicious form, modern political theory degrades into ideologies.

\section{Voegelin's Methodology of Spiritual Realism}

Eric Voegelin's endeavour coincided with the stormy period of World War II. Actually, we may speak about "his war" against the spiritual and intellectual blindness that culminated in the violence of national socialism, the threat of Soviet communism, and the shortcomings of Western liberalism, seventy years ago ${ }^{3}$. He wanted to create a general theory of politics, beyond Max Weber, that embraced the developments of the first half of $20^{\text {th }}$ century Geisteswissenschaften and of Christian anthropology. His aim was to understand how political ideas become effective in history, without limiting himself to a conventional inquiry into the structure of the state. Current political science does not explain the spiritual and counter-spiritual processes that give meaning to existence.

Voegelin's work is comparable in extension to George Sabine's History of Political Thought (1937): in conceptual depth, yet, it is far superior ${ }^{4}$. It helds historicity as an indispensable dimension to unravel the substance of civilization. It is a "history of ideas", because ideas are part of society's self-interpretation and politics exposes human nature in its immediacy. He selects political symbols as ideas or evocations that emerged in human existence. The outcome is a marvellous journey through a kaleidoscope of authors, doctrines and institutions.

Once settled a principle of interpretation, Voegelin questions the conventional ancient-medieval-modern periodization. "Ancient" dilutes the distinction between the archaic period and antiquity itself. "Middle Ages' refers to two long periods of integration and disintegration of the imperial Christian idea, with an ephemeral climax around 1200. "Modernity" spans a period of centuries, emerging in the Middle Ages at the sub-institutional level in "subterranean" authors like Joachim de Fiora and movements like the $15^{\text {th }}$ "people of God"; and continues in the contemporary age as a process of modernization in societies such as $19^{\text {th }}$ century Japan or $20^{\text {th }}$ century Africa ${ }^{6}$. Voegelin was aware that his History of Political Ideas suffered from a major misconception: the supposition of a "march of reason"

\footnotetext{
${ }^{3}$ We know when Voegelin wrote the final chapters of his History of Political Ideas: end of June, 1945. See [2]: "This chapter was finished six weeks before the atom-bomb was dropped on Hiroshima - the date that has brought us one step nearer to the point where reality and comic-strip become indistinguishable".

4 "I started on the materials, using first. as a model of what had to be included or excluded, A History of Political Theory [1937] by George H. Sabine, which at the time was the standard work. But as I began working more deeply the materials, I discovered that the treatment hitherto accorded to them was inadequate and my own knowledge of the materials quite insufficient to deal with them more adequately(...)".

5 The title "History of Ideas" reflects Arthur Lovejoy's programmatic essay in 1939, the first chapter of [3]. In 1940 the same author founded the Journal of the History of Ideas. On the topic, see George Boas in [4. P. 96].

${ }^{6}$ [5. P. 104] «My History of Political Ideas started from the conventional assumptions that there are ideas, that they have a history, and that a history of political ideas would have to work its way from Classical
} 
in history, not triumphant as in Hegel, but a narrative of ascension and fall: later, he labelled this endeavor as "historicism" or "historiogenesis".

In the History of Political Ideas the methodology must be extracted from the materials to which it is applied. If we go too far in this process, we misunderstand what Voegelin calls "evocations", t.i, ordering ideas of political existence that emerge through personal genius, bold movements and resilient institutions.

Each political community realizes an evocation, a founding idea. Voegelin probes the importance of power motives in those evocations, but he does not identify them as causes. Political philosophy and political science should not be based on utilitarian calculus, neither in behaviourist psychology. Pragmatic motivations may be of a spiritual or of anti-spiritual nature; yet, revolt against the spirit takes the structure of the spirit itself. This principle of identity in the spiritual structure of all "evocations" shows that ideas are rooted in the human realm.

The History of Political Ideas' methodology helps him to affirm that political evocations either present or mask reality.

According to Voegelin, it is possible to mask political reality on many accounts, both good and bad: love of fatherland; will to power; well-intentioned utopia; selfishness; opportunism and so on. For instance, renowned thinkers of diverse epochs such as Caius Tullius Cicero, Martin Luther, and the Spaniard Francisco de Vitoria, mask political reality because of their love for their respective nations; they did it with apparent good faith. The "will to power" is what obsesses protagonists such as Frederick II, Egidio Romano, Cardinal Humberto and Cola de Rienza. In 1966 he wrote an essay on Hitler and the Germans - which I prefaced in the Portuguese edition - considering the Nazi dictator an obvious example of will to power in contemporary age [6].

Eric Voegelin points to other ways to cover up reality. He considers that Seneca, Erasmus and Thomas More are prey to a narcissistic mood of utopia; I strongly disagree of this judgement, because Seneca, Erasmus and More were self-critical authors. I think Voegelin is on more sure ground when he points to Epicurus' selfishness or Cromwell's opportunism as ways of masking reality. Reason alone, without a principle of sharing common good, also leads to disguising political reality; it is the case of Locke's possessive individualism and of celebrated Illuminists such as Voltaire, Helvétius and Condorcet. Voegelin also delivers stunning studies about Bakunine's "Revolutionary existence" and Marx's "Gnostic Socialism". They disguise reality in the name of class struggle. Finally in the essays on Auguste Comte's "Apocalypse of Man" - and Nietzsche's "Intramundane Mystique" he considers that these tragic authors escape from reality to the point that reality drove them to madness.

Misrepresenting reality can be a case of pure stupidity — as Robert Musil explained in About Stupidity - or not wanting to see, which Lonergan called skotosis; or of pseudo-reality inventions, which we now call fake news. When the loss of

politics up to the present. Under these assumptions, I humbly worked through the sources, and eventually a manuscript of several thousand pages was in existence». 
ethical and religious substance goes too far, sincerity itself is instrumentalized, as is the case with the Puritan parliamentarians of $17^{\text {th }}$ century England, the French Frondeurs, or King Louis XIV. This theatrical sense of action of "wig-wearing people" anticipates Sorel's general strike myth and Hitler's manipulation of mass psychology. All these personalities and movements are consummate manipulators and we get a contemporary sense of this in the twitter-driven politics of president Trump and other minor populist politicians.

On yet another level, there are doctrinators who appropriate symbols, respecting their form but not their content. This is what Cicero did with natural law; Polybius with mixed government theory; Dante with the "dux ex Babylone" symbol; Althusius, Grotius, and Hobbes with juris rationalism; Locke and Rousseau with the social contract theory; and more. Such doctrines may serve as guides for political action but, from a theoretical perspective, they are hieroglyphics whose origin in consciousness must be deciphered.

Hobbes's understanding of the political role of the persona — the mask is more close to current realism and common sense, a minimal quality for grasping political reality. Authors as different as Polybius, John of Salisbury, Cardinal of Retz, and Warburton had a keen sense of political reality, as they were able to recognize the centre of gravity in human action. They did not lost themselves in abstractions. They recognized power for what it is, but suffered from some blindness about duties.

Above this elementary degree of realism there are authors such as Protagoras, Sigerius of Brabant, Machiavelli. They do not lack political clairvoyance. On the contrary; it was their excess of lucidity that cost them misunderstanding and hatred. They incurred the displeasure of the contemporaries because they "broke the spell", the image of the political world, a cosmion, and provided their own vision. As Voegelin wrote, "It requires more vitality and strength of soul to look at the world unflinchingly than to take refuge in a cosmion." [7. P. 60]

According to Eric Voegelin, the culprit of spiritual realism is found in classical authors such as Plato, Augustine, Aquinas, Bodin, Vico and Schelling. It is puzzling that this short list does not include Aristotle, Descartes or Kant, and admits Bodin, and it is must be remarked that Hegel is put aside as an evil genius. Thus, I am afraid that this short list of major spiritual realists reflects more of Voegelin than of spiritual realism itself.

Plato created a theory of order in classical Athens. His shortcomings arose out of the fact that Hellas had a cosmological horizon that did not allow for a full differentiation of the ens realissimum; the experiences of god and cosmos were still too enmeshed, and the compact truths of the Athenian sage needed differentiation.

Augustine in the $4^{\text {th }}$ century AD and Aquinas in the $13^{\text {th }}$ century managed to separate political society and God and establish a balance between both. The Augustinian dictum "two loves made two cities" — when Christianity was consolidating itself — is a major beacon for the relationship between state and church.

Aquinas' sentence in the Summa contra gentiles — "The order of things in Truth, is the order of things in Being" - means that God, as divine intellect, 
impressed Himself into the structure of the world. The orderly description of the world will result in a system describing the truth of God. More practically, it means that every being, and specifically man, has its meaning in a hierarchy of divine creation and fulfils his existence by ordering it toward God. According to Voegelin, Aquinas dominates the historical panorama through a masterful harmonization of faith and reason and became the voice of medieval imperial Christianity in modern West. "Nobody after him has represented in the same grandiose style the spiritually and intellectually mature Western man"; such historicist sentence has a style of which he got rid himself in his late works.

According to Voegelin, as society evolved, and Christianity survived the civilization in which was born, the task of Christian political philosophers were aggravated by disruptions in the Church. The Great Schism beginning in 1054 separated the Eastern Orthodox Church and the Catholic Church. The Luther Reformation begun in 1517 evolved into a creation of different Christian confessions, engaged in civil wars in Europe. With the global expansion of the West, those confessions spread all over the world. Considering this diversity of confessions, Voegelin picks up for his short list of modern spiritual realists the catholic Giambattist Vico, the Lutheran Friedrich Schelling and the Frenchman Jean Bodin who, in his lifetime, was alternatively labelled a catholic, a protestant and even a "judaizing".

Living in $16^{\text {th }}$ France torn by religious wars, Bodin proposed a new parallel between religious and political order. As a spiritual realist, he perfected the tradition of Plato and Aristotle, enriching it with Hellenistic, Arab, and Jewish speculation. His contemplative temperament allowed him to envisage the republic as a part of the structure of the universe. The purpose of government is the transformation of each national sovereign society into an analogue of the cosmos.

A political cosmion gives a stable existential basis to human life, through law, economics, and religion. Sovereignty is as indispensable tool to keep the political cosmion united. The ultimate end of government is to enable the vision of the divine in human things, in natural causality, in heavenly bodies, in the harmony of the universe, and finally in our relationship and return to in God. Within a stable political ground, a man can ascend to contemplation and fruitio Dei. Such breadth of purpose is rare in political thinkers, and Bodin's heavy and almost prohibitive style does not help him. Who in our time would dare to attribute such ends to political life?

Giambattista Vico's New Science is both a theory of politics, language, art, law and a philosophy of culture. It is a conscious attempt to restore the science of mind against the increasingly accepted natural science model. It is a counterpoint to emergent Enlightenment whose causes were then apparent but the effects not yet visible.

Vico upholds the historicity of human existence; reason does not operate in solitude. Against the Pelagianism of Hugo Grotius that sustains that naturally good man can create social order out of himself, he defends the need of providence for a fallen man. If we understand this tension between justice and evil and the need for providence, we become able to rise above amor sui and utilitarianism. Against 
contract theory, he states that social order is not a result of immanent human action. As a counterpoint to progress and the hybris of self-salvation and optimistic trust in man as the only source of order, he encourages vigilance and care. Progress does not necessarily announces order but, rather, an anarchic struggle for power that ends in Caesarean despotism. The future is open. The corsi and ricorsi of civilization may be transformed by the recursus of Christianity.

Voegelin's essay about Schelling's The realist in an age of disintegration is a very stunning development in any history of political ideas, even his own. He states that Schelling attained a level of critical consciousness, where dialectic legitimates its operations by referring them to a realm of proto-dialectic experiences. He called this experience anamnesis; and anamnesis gives access to a mystical reality that overcomes the historical distinctions between Churches. This endeavour resulted from the necessity to answer the advancement of science and to forge a new method for dealing with nature. Schelling envisages a spirit-minded nature. Proto-dialectic experiences have a meaning that can be projected into society and history. History receives meaning from the soul, while the soul discovers historical meanings as his strata. The system is a last effort of the soul to balance tensions before they broke in the crisis of our time, as extant in the doctrines of Comte, Marx and Bakunine.

We remarked that the centre of Voegelin's research into the substance of politics is the relationship between God and human being - physical, animal, intellectual, moral, spiritual. The spiritual realist must apprehend this tension in order to keep the balance between politics and transcendence. "The spiritual realist is not only the best philosopher, he is also the best empirical scientist." Christianity is imperative because the transcendence of the ens realissimum prevents the absorption of God into the world, society or end of history.

There is a problem, though. Christianity has penetrated history through the institutional Churches and through the temporal gladius. It brought the de-divinization of the cosmos, the end of paganism, the wailing of the old gods. In the long run, yet, Christianity led to a redivinization of the cosmos and society because the image of God became too remote to be humanly sustainable; or too much close to be meaningful. The subterranean movements in High Middle Ages, after Thomas Aquinas' apex in the $13^{\text {th }}$ century initiated the process of redivinization: the elite movements of the Renaissance and Reformation accelerated it; and mass movements in contemporary times brought the apocalypsis of man. Successive waves of Reformation, Enlightenment, Positivism, Marxism, Fascism and Nihilism, culminated in the "crisis of our time". Voegelin wrote in his History of Political Ideas that the only possible unity of the history would be the whole cycle of human history, with Christianity at its summit.

\section{Death and Rebirth of a Book}

We know from Autobiographical Reflections that Voegelin experienced an intellectual apathy in the late 1940s, not of exhaustion but rather a theoretical crisis. He interrupted his almost complete history of political ideas. Were the materials 
inexhaustible? Was the historical linear sequence controversial? Could other methodologies be more reasonable? Were the sources insufficient? The crucial point is that his work contained elements that must be considered as systematic parts of political theory. The problem in the History of Political Ideas is the connection between principles and data. Something was failing. When this insufficiency emerged clearly in Voegelin's mind, the death of his projected book was the necessary condition for the revival of his research. ${ }^{7}$

Later on, Voegelin used materials worked out in the History of Political Ideas. The New Science of Politics, 1952, is a first illustration of his attainments. The first three volumes of Order and History, (vols. I, II and III, 1956-64) rework parts I- $\mathrm{V}$ of History of Political Ideas; they present history as a compromise between order in personal consciousness and order in society. Anamnesis, 1966, displays a philosophy of consciousness based on the Schelling's experience of participation. The Ecumenical Age (vol. IV of Order and History, 1974) incorporates decisive elements about the Hellenistic period and highlights the equivalence of symbols in history. Christian revelation emerges as a resource of faith in search of reason and an announcement of the "unknown god" in the in-between of human life.

In my opinion, Voegelin did not finish his History of Political Ideas, because he realized that history is no substitute for the human experience of awakening. Again: the death of his book was the necessary condition for the revival of his research. Ideas are not autonomous beings; they are not endowed with a "history"; they are symbols through which each person and each people express himself or herself. The vocabulary of "ideas" and "values" results from a "doctrinalization" of philosophy.

The task of the political philosopher is to liberate himself from inadequate methods. "The focus of my interest thus moved from ideas to the experiences of reality that engendered the variety of symbols." [9. P. 78-80]. Eric Voegelin's work surely has a major place in the recovery of political theory carried out in the $20^{\text {th }}$ century by many voices. We must put him along philosophers such as Franz Rosenzweig, Henri Bergson and Emmanuel Lévinas. We can compare him with the theories of history of Oswald Spengler and Arnold Toynbee. He evokes analysts of modern rebellion such as Hannah Arendt and Albert Camus. He sympathized with thioe who recovered the role of myth in pre-philosophical civilizations (Henry Frankfort, Mircea Eliade, Wilhelm Jaeger). He was aware of the epistemologies of the tacit dimensions of science (Michael Polanyi, Bernard Lonergan).

"I gave up the project of a History of Political Ideas and started my own work on Order and History". ${ }^{8}$ The non-publication of the History of Political Ideas is

\footnotetext{
7 "Giambattista Vico" [8. P. 101 e 138].

8 "My work on the History of Political Ideas had not been done in vain, because it had familiarized me with the historical sources. But now, the reorganization of the materials under the aspect of experience and symbolization became necessary. Hence, I gave up the project of a History of Political Ideas and started my own work on Order and History" [9. P. 80]
} 
mitigated as we confront the 2600 extant pages of the 8 volumes with Voegelin's later work. My own work. Let us enhance this sentence. It shows that Voegelin emerged renewed from his theoretical struggle as he moved from the history of ideas to the analysis of the experience of consciousness. The History of Political Ideas was not an oeuvre depassée. Despite its omissions, shortcomings and incompleteness, it become a womb out of which successive contents were born. It was not a dead dinosaur. It was rather a provisional collection of the "bones of contention" of the zoon politikon that Voegelin sought to define during his lifetime.

\section{Bibliography}

\section{Selected Works of Eric Voegelin - ENGLISH}

[1] ORDER AND HISTORY. 5 vol. subset. In: Collected Works of Eric Voegelin. Vol. 14-18.

[2] Voegelin E. Israel and Revelation. Vol. I. Ed. with an intro. by Maurice Hogan. In: Collected Works of Eric Voegelin. Vol. 14. University of Missouri; 2001.

[3] Voegelin E. World of the Polis. Vol. II. Ed. with an intro. by Athanasios Moulakis. In: Collected Works of Eric Voegelin. Vol. 15. University of Missouri; 2000.

[4] Voegelin E. Plato and Aristotle. Vol. III. Ed. with an intro. by Dante Germino. In: Collected Works of Eric Voegelin. Vol. 16. University of Missouri; 2000.

[5] Voegelin E. The Ecumenic Age. Vol. IV. Ed. with an intro. by Michael Franz. In: Collected Works of Eric Voegelin. Vol. 17. University of Missouri; 2000.

[6] Voegelin E. In Search of Order. Vol. V. Ed. with an intro. by Ellis Sandoz. In: Collected Works of Eric Voegelin. Vol. 18. University of Missouri; 2000.

[7] HISTORY OF POLITICAL IDEAS. 8 vol. subset. In: Collected Works of Eric Voegelin. Vol. 19-26. Series Editor Ellis Sandoz.

[8] Voegelin E. History of Political Ideas. Vol. I. Hellenism, Rome, and Early Christianity. General Introduction by Thomas Hollweck \& Ellis Sandoz. Ed. with an intro by Athanasios Moulakis. In: Collected Works of Eric Voegelin. Vol. 19. University of Missouri; 1997.

[9] Voegelin E. History of Political Ideas. Vol. II. The Middle Ages to Aquinas. Ed. with an intro by Peter von Sivers. In: Collected Works of Eric Voegelin. Vol. 20. University of Missouri; 1997.

[10] Voegelin E. History of Political Ideas. Vol. III. The Later Middle Ages. Ed. with an intro. by David Walsh. In: Collected Works of Eric Voegelin. Vol. 21. University of Missouri; 1997.

[11] Voegelin E. History of Political Ideas. Vol. IV. Renaissance and Reformation. Ed. with an intro. by David L. Morse \& William M. Thompson. In: Collected Works of Eric Voegelin. Vol. 22. University of Missouri; 1997.

[12] Voegelin E. History of Political Ideas. Vol. V. Religion and the Rise of Modernity. Ed. with an intro. by James L. Wiser. In: Collected Works of Eric Voegelin. Vol. 23. University of Missouri; 1997.

[13] Voegelin E. History of Political Ideas. Vol. VI. Revolution and the New Science. Ed. with an intro. by Barry Cooper. In: Collected Works of Eric Voegelin. Vol. 24. University of Missouri; 1997.

[14] Voegelin E. History of Political Ideas. Vol. VII. The New Order and Last Orientation. Ed. with and intro. by Jürgen Gebhardt \& Thomas A. Hollweck. In: Collected Works of Eric Voegelin. Vol. 25. University of Missouri; 1997. 
[15] Voegelin E. History of Political Ideas. Vol. VIII. Crisis and the Apocalypse of Man. Ed. with an intro by David Walsh: includes cumulative index of all eight volumes of the History. In: Collected Works of Eric Voegelin. Vol. 26. University of Missouri; 1999.

[16] Autobiographical Reflections \& Cumulative Index, by Linda Webster. Ed. with an intro. by Ellis Sandoz. In: Collected Works of Eric Voegelin. Vol. 34. University of Missouri; 2006.

[17] Voegelin E. Anamnesis. trans. M. J. Hanak. Ed. with an intro. David Walsh. In: Collected Works of Eric Voegelin. Vol. 6. University of Missouri; 2001.

\section{Eric Voegelin's Works - PORTUGUESE}

[18] Voegelin E. A Nova Ciência da Politica. Brasília;1979.

[19] Voegelin E. Estudos de ideias políticas de Erasmo a Nietzsche. Editor Henriques, Mendo Castro. Lisboa: Ática; 1996.

[20] Voegelin E. Ordem e História, Vol. I: Israel e a Revelação. São Paulo: Edições Loyola; 2009.

[21] Voegelin E. Ordem e História, Vol. II: O Mundo da Pólis. São Paulo: Edições Loyola; 2009.

[22] Voegelin E. Ordem e História, Vol. III: Platão e Aristóteles. São Paulo: Edições Loyola;2009.

[23] Voegelin E. Ordem e História. Vol. IV: A Era Ecuménica. São Paulo: Edições Loyola; 2010.

[24] Voegelin E. Ordem e História. Vol. V: Em Busca da Ordem. São Paulo: Edições Loyola; 2010.

[25] Voegelin E. Anamnese - Da teoria da história e da política. Trad. Elpídio Fonseca. São Paulo: É Realizações; 2009.

[26] Voegelin E. Hitler e os Alemães. trad. Elpídio Fonseca. Pref. Mendo Castro Henriques. São Paulo: É Realizações; 2008.

[27] Voegelin E. Reflexões Autobiográficas. Trad: Carvalho, Maria Inês de. São Paulo: É Realizações; 2008.

[28] Voegelin E. Helenismo, Roma e Cristianismo Primitivo - História das Ideias Políticas. Vol. I. Trad. Mendo Castro Henriques. São Paulo: É Realizações; 2009.

[29] Voegelin E. Idade Média até Tomás de Aquino - História das Ideias Políticas. Vol. II. Trad. Mendo Castro Henriques. São Paulo: É Realizações; 2012.

[30] Voegelin E. Idade Média Tardia - História das Ideias Políticas. Vol. III. Trad. Mendo Castro Henriques. São Paulo: É Realizações; 2013.

[31] Voegelin E. Renascença e Reforma - História das Ideias Políticas. Vol. IV. Trad. Elpídio Fonseca. São Paulo: É Realizações; 2014.

[32] Voegelin E. Religião e a Ascensão da Modernidade - História das Ideias Políticas. Vol. V. Trad. Elpídio Fonseca. São Paulo: É Realizações; 2016.

[33] Voegelin E. Revolução e a Nova Ciência - História das Ideias Políticas. Vol. VI. Trad. Elpídio Fonseca. São Paulo: É Realizações; 2017.

[34] Voegelin E. A Nova Ordem e a Última Orientação — História das Ideias Políticas. Vol. VII. Trad. Elpídio Fonseca. São Paulo: É Realizações; 2017.

[35] Voegelin E. A Crise e o Apocalipse do Homem — História das Ideias Políticas. Vol. VIII. Trad. Elpídio Fonseca. São Paulo: É Realizações; 2018.

[36] Fé e Filosofia Política - A correspondência entre Leo Strauss e Eric Voegelin (1934-1964). São Paulo: É Realizações; 2017. 


\title{
Works about Voegelin in Portuguese
}

[37] Federici, Michael P. Eric Voegelin - A Restauração da Ordem. São Paulo: É Realizações; 2011.

[38] Henriques, Mendo Castro. Filosofia Política em Eric Voegelin — dos megalitos à era espacial (Livro + 3 DVDs). São Paulo: É Realizações; 2009.

[39] Henriques, Mendo Castro. A Filosofia Civil de Eric Voegelin. São Paulo: É Realizações; 2010.

[40] Sandoz, Ellis. A Revolução Voegeliniana. São Paulo: É Realizações; 2010.

\section{References}

[1] Voegelin E. Autobiographical Memoir. In: Ellis Sandoz. The Voegelinian Revolution. Baton Rouge: Louisiana State University Press; 1981.

[2] Voegelin E. History of Political Ideas. Vol. VII. The New Order and Last Orientation. Ed. with and intro. by Jürgen Gebhardt \& Thomas A. Hollweck. In: Collected Works of Eric Voegelin. Vol. 25. University of Missouri; 1997.

[3] Lovejoy AO. Essays in the History of Ideas. The Johns Hopkins Press, Baltimore: London, Cumberlege; 1948.

[4] Edwards P (ed.). The Encyclopedia of Philosophy. Vol. 5. Collier-Macmillan; 1967.

[5] Autobiographical Reflections \& Cumulative Index, by Linda Webster. Ed. with an intro. by Ellis Sandoz. In: Collected Works of Eric Voegelin. Vol. 34. University of Missouri; 2006.

[6] Voegelin E. Hitler e os Alemães. trad. Elpídio Fonseca. Pref. Mendo Castro Henriques. São Paulo: É Realizações; 2008.

[7] Voegelin E. History of Political Ideas. Vol. VII. The New Order and Last Orientation. Ed. with and intro. by Jürgen Gebhardt \& Thomas A. Hollweck. In: Collected Works of Eric Voegelin. Vol. 25. University of Missouri; 1997.

[8] Voegelin E. History of Political Ideas. Vol. VI. Revolution and the New Science. Ed. with an intro. by Barry Cooper. In: Collected Works of Eric Voegelin. Vol. 24. University of Missouri; 1997.

[9] Autobiographical Reflections \& Cumulative Index, by Linda Webster. Ed. with an intro. by Ellis Sandoz. In: Collected Works of Eric Voegelin. Vol. 34. University of Missouri; 2006.

\section{About the author:}

Castro-Henriques Mendo - Catholic University of Portugal, School of Human Sciences, Auxiliary Professor, PhD in Political Philosophy (e-mail: mendohenriques@ucp.pt).

\section{«История политических идей» Эрика Фёгелина. Абрис концепций политического животного}

\section{М. Кастро-Хенрикес}

\author{
Universidade Católica Portuguesa (UCP) \\ Palma de Cima, 1649-023 Lisbon, Portugal
}

«История политических идей» немецко-американского философа Эрика Фёгелина (1901-1985) представляет собой монументальное произведение объемом около 
2600 страниц. Оно оставалось неопубликованным при его жизни и впервые увидело свет благодаря американскому изданию (1997-1999 годы) и ныне завершенному португальскому изданию (2012-2018 годы). Будучи автором первого в мире издания сокращенной версии «Истории политических идей», переводчиком первых трех томов португальского издания 2012-2018 годов, и автором ““Гражданской философии” Эрика Фёгелина», я считаю, что «История политических идей» бросает вызов нынешнему разнообразию философских позиций: она подрывает разъедающие силы морального релятивизма, нетерпимого неопозитивизма, навязчивые идеи о конце истории, постмодернистские деконструкции, агностицизм, нигилизм, религии нового времени и всепроникающую идеологию денег. Эрик Фёгелин добивается всего этого, ведя своих читателей от античности до современности. Его монументальная работа начинается с «духовного распада» греческого мира, после Платона и Аристотеля. Распада, который положил начало долгому процессу перехода к самопониманию человека в средиземноморском мире. Через Средние века, Ренессанс и Реформацию Фёгелин анализирует крах имперского христианства, который привел к росту автономного разума и восстаниям на религиозной почве, достигшим полного развития в последующие века. Новая форма современного человеческого сознания заменила христианское понимание божественно созданного закрытого космоса. Фёгелин оставляет открытую концовку, заявляя о «Кризисе и Апокалипсисе человека». Он рассматривает таких мыслителей, как Конт, Бакунин и Маркс. Хотя они испытали истинное прозрение, они стали одержимыми собой и собственными идеями в ущерб миру, о котором рассуждали. Такой «Апокалипсис человека» теперь должен быть поставлен под сомнение вместе с методологиями и герменевтическими принципами, от которых сам Фёгелин отказался несколько десятилетий назад.

Ключевые слова: философия, политология, история идей, политическая история, духовный реализм, гражданское богословие, методология, просвещение, реформация, позитивизм

\section{История статьи:}

Статья поступила 12.08.2019

Статья принята к публикации 24.09.2019

Для цитирования: Кастро-Хенрикес M. «История политический идей» Эрика Фёгелина. Абрис концепций политического животного // Вестник Российского университета дружбы народов. Серия: Философия. 2020. Т. 24. o 1. С. 99-112. DOI: $10.22363 / 2313-2302-2020-24-1-99-112$

\section{Сведения об авторе:}

Кастро-Хенрикес Мендо - доктор философии, профессор, приглашенный профессор факультета теологии Католического университета Португалии (e-mail: mendohenriques@ucp.pt). 